\title{
Interactions of tone and ATR in Slovenian*
}

\author{
Michael Becker, University of Massachusetts Amherst \\ Peter Jurgec, CASTL, University of Troms $\varnothing$
}

\section{Introduction}

The interaction of tone with vowel quality is rarely reported. In fact, Hombert (1977) and de Lacy (2007) deny that such interactions are possible. We present a particularly clear case of synchronic interaction of tone with vowel quality in Slovenian as a counter-example. Slovenian restricts the combination of high tones with lax mid vowels by adjusting the tone in the native phonology and adjusting the vowel quality in the loanword phonology. We use this case to motivate an Optimality Theoretic (Prince \& Smolensky, 1993/2004) analysis of Slovenian using a markedness constraint that penalizes high tones on lax vowels.

Most reports of vowel-segment interaction involve the effect of consonants on tone, most commonly the lowering effect of voiced obstruents and the raising effect of voiceless ones (Hyman \& Schuh 1974, Hombert 1978, Hombert et al. 1979, Tang 2008, inter alia). As for vowel quality-tone interactions, the most well studied case is Fuzhou (Jiang-King 1999), in which syllables with tense mid vowels can have H, HM, or M tone, while those with lax mid vowels have HL or ML. In Cantonese (Yue Hashimoto 1972), High tone is restricted in closed syllables: on the tense vowels higher tone surfaces compared to lax vowels. In Hu (Svantesson 1991:72), high vowels always have High tone in closed syllables, but both $\mathrm{H}$ and L are allowed in open syllables. In Lahu (Matisoff 1973), a rising tone raises the vowel. Shua (Odden 2007) contrasts H, M and L on non-high vowels, but high vowels also contrast a fourth, Super High tone. In Tupuri (Odden 2007), both

\footnotetext{
*We would like to thank Paul de Lacy, Larry Hyman, John Kingston, Charles Kisseberth, John McCarthy, Bruce Morén, David Odden, Curt Rice, Lisa Selkirk, Matthew Wolf, Draga Zec, and the participants of the Workshop on Segments and Tone (Amsterdam, June 2007). Any remaining errors are ours.
} 
consonants and vowel height determine tone in the imperative: high vowels require High or Super High tone (for further information on the three-way interaction of obstruent voicing, vowel height and tone, see Kingston 2007). In Matsue Japanese (Nitta 2001), the position of an initial rise depends on vowel height: the rise is on the second vowel of the word if the second and third vowels are high, but the rise is on the third if only the second is high. In Awad Bing (Cahill 2001), vowel-initial words have a Low tone, except for initial [i], which has a High tone. These reports lend support to the view that higher or tense vowels prefer High tones, and lower or lax vowels prefer Low tones.

In other languages, however, the opposite is true. In Taiwanese (Zee 1980), high tone correlates with higher F1, or a lower vowel. In Rengao (Gregerson 1976), tense vowels select lower tones than lax vowels. In Western Cham (Edmondson \& Gregerson 1993), tense vowels have consistently lower pitch than low vowels. In Madurese (Trigo 1991, Cohn 1993), the relationship between tone and vowel height is only indirect: voiceless obstruents increase the fundamental frequency and change vowel quality, such that only lax vowels are possible after plain voiceless onsets. In Kanazawa Japanese (Nitta 2001, Odden 2001), the initial rise depends on vowel height and onset voicing: in words with a voiced onset and a high vowel in the second syllable, the pitch rise occurs on the second syllable if the third vowel is also high, but if the third vowel is non-high, the rise is word-initial. Low vowels in some languages prefer high tone. For example, Ngizim has a predictable High tone on [a] in verbs (Schuh 1971). Similar cases exist in Eastern Maninkakan (Spears 1968) and Kinande (Mutaka 1994, Archangeli \& Pulleyblank 1994).

Diachronic effects of vowel quality on tone are reported in Limburg Dutch (Hermans \& van Oostendorp 2007, and references therein) and U (Svantesson 1988, 2001). In these two languages, high vowels triggered the development of High tones.

The correlation between vowel height and tone is phonetically grounded. Higher vowels have higher intrinsic $F_{0}$ than lower vowels, since the raised tongue tenses the vocal 
cords (Ohala 1973, 1978, Ohala \& Eukel 1987), as has been reported for a large number of languages (e.g. Hombert et al. 1979, Whalen \& Levitt 1995, Connel 2002). However, there is also a phonetic grounding for the opposite pattern, in which low vowels give rise to higher $\mathrm{F}_{0}$. Larynx height correlates directly with $\mathrm{F}_{0}$; raising the larynx shortens the vocal tract, which in turn raises the formant frequencies, particularly $F_{1}$, resulting in a somewhat lower vowel quality (Hombert et al. 1979, Archangeli \& Pulleyblank 1994). Moreover, speakers who have shorter vocal tracts will have higher $\mathrm{F}_{0}$ and higher formant frequencies, so across speakers, higher pitch correlates with higher $F_{1}$, or lower vowels. In perception experiments, this effect was found significant (Fant 1970, Assmann \& Nearey 2007).

These sources of two opposite correlations between $F_{0}$ and $F_{1}$ have led to claims that the overall correlation is too small to have any phonological consequences, as suggested by Hombert (1977). In a perception experiment, high vowels were judged significantly higher than low vowels with the same pitch, but Hombert attributes this effect to the vowels' spectral properties. Furthermore, while Connel (2002) finds significant influence of Low tone on $\mathrm{F}_{1}$, this is not true for other tones, for mid vowels, or languages that have more than two tones. Zee (1980) finds that speakers differ on whether $F_{0}$ and $F_{1}$ of individual vowels correlate positively or negatively. Pape \& Mooshammer (2006) report that intrinsic $\mathrm{F}_{0}$ is language dependent. Kingston (2007) shows that there are no automatic $\mathrm{F}_{0}-\mathrm{F}_{1}$ correlations in American English. In addition, it has been suggested that for many languages mentioned above, where tone and vowel quality interact, there is some other phonetic dimension that interacts with tone, such as phonation type or vowel duration. Examples of languages where the interaction between tone and vowel quality is mediated by additional factors include Turkana, which involves the mediation of phonation type (Dimmendaal 1983, Dimmendaal \& Breedveld 1986), and also Fuqing (Jiang-King 1999) and Thai (Abramson 1962, Morén \& Zsiga 2006), which involve the mediation of vowel length. Finally, the precise nature of vowel-tone interaction may be obscured considerably 
by complex tones, as in Cantonese and Fuzhou, or additional consonant-tone interaction as in Tupuri, Madurese and Kanazawa Japanese.

The phonology of Slovenian, which we discuss here, offers a clear case of tone-vowel interaction that isn't complicated by consonant quality, phonation type, or syllable structure. Slovenian shows that lax vowels preferably occur with Low tones and tense vowels with High tones. In the native phonology, lax mid vowels are disallowed with High tones. In the loanword phonology, only High tones are allowed, and hence mid vowels are tensed to fit them. This uniformity of target and heterogeneity of process is a hallmark of markedness in Optimality Theory. We propose the markedness constraint $* \mathrm{H} /[-\mathrm{ATR}-\mathrm{low}]$, and show its ranking in the native and loanword phonologies of Slovenian. No other phonological property can be held responsible for this interaction.

\section{The nominal system of Slovenian}

This paper focuses on the nominal system of Standard Slovenian, as it is spoken in Ljubljana (henceforth, Slovenian), also the dialect of the alphabetically second author. Slovenian contrasts two tones on the stressed syllable, High and Low, as in (1).

$$
\begin{array}{ll}
\text { 'pót } & \text { 'path' } \\
\text { pòt } & \text { 'sweat' }
\end{array}
$$

Our focus is on nominal paradigms, which are representative of the phonology of the language. With six cases and three numbers, Slovenian nouns are richly inflected. For the majority of nouns, the tones and stress do not change throughout the nominal paradigm, shown by the representative examples in (2). 
(2)

$\begin{array}{lll}\text { NOM.SG } & \text { ko'rák } & \text { be'dàk } \\ \text { GEN.SG } & \text { ko'rák-a } & \text { be'dàk-a } \\ \text { NOM.PL } & \text { ko'rák-i } & \text { be'dàk-i } \\ \text { INSTR.DU } & \text { ko'rák-oma } & \text { be'dàk-oma } \\ & \text { 'step' } & \text { 'fool' }\end{array}$

Previous descriptions of Slovenian tone contain conflicting accounts of tones that appear after the stressed syllable (Toporišič 1968, 2000, Herrity 2000, Lenček 1981, Srebot Rejec 1988). However, Jurgec $(2007 \mathrm{a}, \mathrm{b})$ shows that these tones are boundary tones that are assigned at the phonological phrase level, as evidenced by their absence inside compounds. Since this paper deals with the word-level phonology of the nominal system, we abstract away from these phrase-level tones, which do not impinge on the word-level tones we discuss here.

Stress in Slovenian correlates with increased duration and intensity (Srebot Rejec 1988). Unstressed vowels are subject to reduction, both of the neutralizing and the non-neutralizing kinds (Jurgec 2005, 2006). Contrary to the traditional account (Toporišič 2000), there is no distinctive length contrast on vowels (Srebot Rejec 1988, Petek et al. 1996, Šuštaršič et al. 1995, 1999). Slovenian has nine contrastive vowel qualities in stressed syllables, but only five in unstressed syllables (3).

(3) Slovenian vowel system
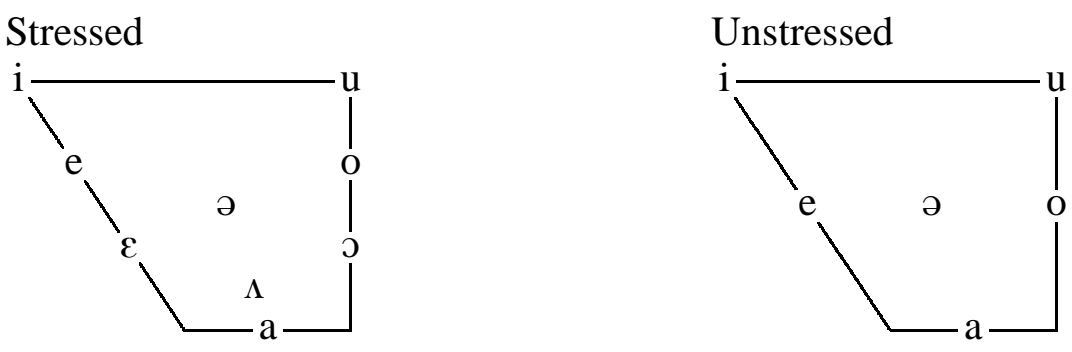
In stressed syllables, the unmarked vowels $\{\mathrm{a}, \mathrm{e}, \mathrm{i}, \mathrm{o}, \mathrm{u}\}$ can appear with either a High or a Low tone anywhere a stressed vowel is allowed. In other words, there is no restriction on their distribution beyond the restrictions that apply to the category 'vowel'. Examples of the mid vowels [e] and [o] are in (4). Since all but a few native roots are maximally disyllabic, we present examples of roots with final and penultimate stress, but not antepenultimate stress.

(4) Distribution of tones on $[+\mathrm{ATR}]$ mid vowels

\begin{tabular}{lllll}
\hline & Final stress & \multicolumn{3}{c}{ Penultimate stress } \\
\hline e & pe'pél $\sim$ pe'pél-a & 'ash' & 'jézer-o $\sim$ 'jézer-a & 'lake' \\
& i'mè $\sim$ i'mèn-a & 'name' & 'dète $\sim$ 'dètet-a & 'baby' \\
\hline \multirow{2}{*}{ o } & ko'kó $\sim$ ko'kóf-i & 'chicken' & 'vójvot $\sim$ 'vójvod-a & 'duke' \\
& o'bòk $\sim$ o'bòk-a & 'arch' & 'pògrat $\sim$ 'pògrad-a & 'bunk, bed' \\
\hline
\end{tabular}

\section{Roots with underlying tone}

We limit the discussion to roots with underlying tone; they constitute the vast majority of all nouns in Slovenian. These nouns have fixed stress and tone (with some exceptions, see below) throughout the paradigm, and contrast High and Low tones (2). In Slovenian, only one tone per Prosodic Word is allowed, which we attribute to the effect of (5).

\section{$\mathrm{T} / \Delta_{\sigma} \mathrm{PWd}$}

Every mora associated with a tone (either High or Low) must be dominated by the head syllable of the Prosodic Word. 
Hence, for an input with one underlying tone in the root and one in a suffix, only one tone will surface faithfully, the one in the root. The constraint in (6) ensures that a tone from a suffix doesn't flop over to the stressed syllable and surface there.

\section{NoFLOP (Alderete 2001:216)}

If output tone $t^{\prime}$ corresponds to input tone $t$, and output mora $m^{\prime}$ corresponds to input mora $m$, and $t$ and $m$ are associated, assign one violation mark iff $t^{\prime}$ and $m^{\prime}$ are not associated, and $t^{\prime}$ is associated to some other mora $m^{\prime \prime}$.

The tableau in (7) exemplifies this point. The candidates (b) and (c) violate $\mathrm{T} / \Delta_{\sigma} \mathrm{PWd}$ and NoFLOP respectively, which in turn must be ranked above the $\operatorname{MAX}(\mathrm{T})$ constraint. Note that this result only holds if both tones are underlyingly associated with a vowel (i.e. not floating), see (10) for further examples.

be'dàk-a 'bedak.NOM.DU'

\begin{tabular}{|c|c|c|c|}
\hline $\begin{array}{c}\mathrm{L} \\
\text { /bedak-a } \\
\mathrm{H}\end{array}$ & $\mathrm{T} / \Delta_{\sigma} \mathrm{PWd}$ & NoFLOP & $\operatorname{MAX}(\mathrm{T})$ \\
\hline a. [be'dàka] & & & $*$ \\
\hline b. [be'dǎka] & & $* !$ & \\
\hline c. [be'dàká] & $* !$ & & \\
\hline
\end{tabular}

Some nouns do not have the same tone throughout their paradigm. The feminines contrast High and Low on most members of the paradigm, but the INST.SG and GEN.PL are normally High in most feminine declension classes. The paradigms in (8) represent the vast majority of feminine nouns. 


$\begin{array}{llll}\text { NOM.SG } & \text { 'slúzb-a } & \text { ma'lìn-a } & \text { 'pàmet } \\ \text { GEN.SG } & \text { 'slúzb-e } & \text { ma'lìn-e } & \text { 'pàmet-i } \\ \text { INST.SG } & \text { 'slúzb-o } & \text { ma'lín-o } & \text { 'pámet-jo } \\ \text { NOM.PL } & \text { 'slúzb-e } & \text { ma'lìn-e } & \text { 'pàmet-i } \\ \text { GEN.PL } & \text { 'slúfp } & \text { ma'lín } & \text { 'pàmet-i } \\ & \text { 'job' } & \text { 'raspberry' } & \text { 'mind' }\end{array}$

We propose that suffixes that have a floating tone trump lexical tone. The underlying Low on ['pámet-jo] is replaced by the floating High of the INST.SG due to the MAX(float) constraint in (9), which prefers the realization of floating tones ${ }^{1}$.

\section{$\operatorname{MAx}($ float) (Wolf 2007)}

If a tone $t$ in the input is not linked to a mora, $t$ must have an output correspondent.

The derivation of ['pámet-jo] is in (10). The floating tone is preserved due to high ranked $\operatorname{MAX}($ float), which outranks MAX(T).

'pámetjo 'wisdom.INST.SG'

\begin{tabular}{|c|c|c|}
\hline$\stackrel{\text { L }}{\mid} \underset{\mid}{\mathbf{H}}$ & MAX(float) & $\operatorname{MAX}(\mathrm{T})$ \\
\hline a. ['pámetjo] & & * \\
\hline b. ['pàmetjo] & $* !$ & \\
\hline
\end{tabular}

Interestingly, floating tones dock onto the vowel that has the underlying tone. If we accept the NOM.SG ['pàmet] as the base for assessing Output-to-Output-faithfulness, then OO-IDENT(stress) is sufficient to exclude candidate (b) in (11).

\footnotetext{
${ }^{1}$ Wolf (2007) motivates this constraint based on an analysis of phenomena that are unrelated to tone, such as consonant mutations. The current analysis lends support to this constraint. Note that the REALIZEMORPHEME (Kurisu 2001) constraint would not suffice, since most of these suffixes are also segmentally realized.
} 
(11)

'pámetjo 'wisdom.INST.SG'

\begin{tabular}{|c|c|c|}
\hline $\begin{array}{c}\mathrm{L} \\
/ \\
/ \text { pamet-jo }\end{array}$ & NOFLOP & OO-IDENT(stress) \\
\hline a. $[$ 'pámetjo] & & \\
\hline b. [pa'métjo] & & $* !$ \\
\hline
\end{tabular}

\section{Tone-vowel interactions}

Tone is predictable on the marked vowels $\{\varepsilon, \partial, \Lambda, \partial\}$. In this paper we discuss the mid vowels, although the situation is similar-yet more complex—for the other two vowels. In paradigms with fixed stress, which normally contrast High and Low tones on the unmarked vowels [e] and [o] (see section 3), [ع] and [o] show up with predictable tone: Low tone on all members of the paradigm, except the NOM.SG and GEN.PL.

$\begin{array}{lllll}\text { NOM.SG } & \text { pro'mét } & \text { rép } & \text { uz'rók } & \text { brón } \\ \text { GEN.SG } & \text { pro'mèt-a } & \text { 'rèp-a } & \text { uz'ròk-a } & \text { 'bròn-a } \\ \text { NOM.PL } & \text { pro'mèt-i } & \text { 'rèp-i } & \text { uz'ròk-i } & \text { 'bròn-i } \\ \text { GEN.PL } & \text { pro'mét-ow } & \text { 'rép-ow } & \text { uz'rók-ow } & \text { 'brón-ow } \\ & \text { 'traffic' } & \text { 'tail' } & \text { 'cause' } & \text { 'bronze' }\end{array}$

In a few nouns, $[\varepsilon]$ and $[0]$ can appear as the root's penult vowel, but the penult gets stressed only in the NOM.SG. Again, $[\varepsilon]$ and $[0]$ show up with a Low tone (13).

$\begin{array}{lll}\text { NOM.SG } & \text { 'ť̀le } & \text { 'òtfe } \\ \text { GEN.SG } & \text { te'lèt-a } & \text { o'tfèt-a } \\ \text { NOM.PL } & \text { te'lèt-a } & \text { o'tfèt-je } \\ \text { GEN.PL } & \text { te'lèt } & \text { o'tfèt-ow } \\ & \text { 'calf' } & \text { 'father' }\end{array}$


Missing from the language are fixed stress paradigms with $[\varepsilon]$ or [o] and a High tone throughout. We assume that such hypothetical inputs map onto the Low tone paradigms. Since $[\varepsilon]$ and $[\supset]$ do not allow faithfulness to High vs. Low, there must be some markedness constraint that prefers Low on $[\varepsilon]$ and [o]. More formally: $* \mathrm{H} /[-\mathrm{ATR}-\mathrm{low}]$. The phonetic grounding for the required markedness constraint is reasonable: Higher vowels correlate with higher perceived pitch, and [-ATR] correlates with lower vowels, so the combination is dispreferred; in fact, most languages display this pattern, as outlined in the introduction. We illustrate this in tableau (14). Candidate (a) violates high ranked $* \mathrm{H} /[-\mathrm{ATR}-\mathrm{low}]$, which outranks the corresponding faithfulness constraint MAX(T). ka'tèpa (hypothetical)

\begin{tabular}{|c|c|c|}
\hline$\stackrel{\mathrm{H}}{\mathrm{I}}^{\mathrm{k} \text { katep-a/ }}$ & $* \mathrm{H} /[-\mathrm{ATR}-\mathrm{low}]$ & $\operatorname{MAX}(\mathrm{T})$ \\
\hline a. [ka'tépa] & $* !$ & \\
\hline b. $[\mathrm{ka}$ 'tèpa] & & $*$ \\
\hline
\end{tabular}

A floating tone, however, causes $[\varepsilon]$ or $[0]$ to surface with a High tone in the NOM.SG and GEN.PL (15), due to the high ranked MAX(float). pro'métow 'traffic.GEN.PL'

\begin{tabular}{|c|c|c|c|}
\hline $\begin{array}{c}\mathrm{L} \quad \mathrm{H} \\
/ \text { pro'met-ow/ }\end{array}$ & MAX(float) & $* \mathrm{H} /[-\mathrm{ATR}-\mathrm{low}]$ & $\operatorname{MAX}(\mathrm{T})$ \\
\hline a. [pro'mètow] & $* !$ & & * \\
\hline b. $[$ pro'métow] & & $*$ & $*$ \\
\hline
\end{tabular}

\section{Loanword phonology}

Evidence for the markedness of High tones on mid vowels also comes from the loanword phonology. In loanwords, a High tone is required, and mid vowels are raised to accom- 
modate it (Jurgec 2007b), which is just the opposite of the native pattern, where tone accommodates vowel quality. For instance, English [0] is borrowed as [o], even when either choice of vowel is allowed in the native phonology, as evidenced by the cases in (16), where either choice of vowel is an actual native word.

Absence of [ - ATR $]$ vowels in assimilated loanwords

\begin{tabular}{|c|c|c|c|c|c|}
\hline \multicolumn{2}{|c|}{ Native $[+$ ATR $]$} & \multicolumn{2}{|c|}{ Native [-ATR] } & \multicolumn{2}{|c|}{ Foreign [+ATR] (only) } \\
\hline rók & 'hand.GEN.PL' & rók & 'deadline' & rók & 'rock' \\
\hline ós & 'wasp.GEN.PL' & ós & 'axis' & ós & 'Oz' \\
\hline mét & 'sword' & mét & 'calf.GEN.PL' & mét & 'match' \\
\hline 'kòla & 'rod.GEN.SG' & 'kóla & 'kolo.GEN.SG' & 'kóla & 'cola' \\
\hline
\end{tabular}

The loanword phonology respects $* \mathrm{H} /[-\mathrm{ATR}-\mathrm{low}]$, just like the native phonology. While the native phonology repairs violations of $* \mathrm{H} /[-\mathrm{ATR}-\mathrm{low}]$ by changing a High tone to Low, the loanword phonology repairs these violations by changing the tenseness of the vowel. The same markedness constraint is active in both parts of the lexicon, but the activity of an additional markedness constraint in the loanword phonology forces a different repair.

The example in (17) is repeated from (14), with the added candidate (c), which is unfaithful to [ATR]. With faithfulness to [ATR] ranked above faithfulness to tone, the vowel quality is kept, and the tone is changed. 


\begin{tabular}{|c|c|c|c|}
\hline$\stackrel{\mathrm{H}}{\mathrm{l}}^{\mathrm{k}} \mathrm{kat} \mathrm{p}-\mathrm{a} /$ & $* \mathrm{H} /[-\mathrm{ATR}-\mathrm{low}]$ & MAX(ATR) & $\operatorname{MAX}(T)$ \\
\hline a. $[\mathrm{ka}$ 'tèpa] & & & * \\
\hline b. [ka'tépa] & *! & & \\
\hline $\begin{array}{ll}\text { c. } & \text { [ka'tépa] }\end{array}$ & & $* !$ & \\
\hline
\end{tabular}

In the loanword phonology, where only High tones are allowed (with a few templatic exceptions, see Jurgec 2007b), the vowel must change to fit the tone. The tableau in (18) illustrates the situation in the loanword phonology, with a high-ranking constraint against low tones on the head of the Prosodic Word $\left({ }^{*} \Delta_{\sigma} \mathrm{PWd} / \mathrm{L}\right.$, de Lacy 2002).

métf 'match'

\begin{tabular}{|c|c|c|c|}
\hline /met / & ${ }^{*} \Delta_{\sigma} \mathrm{PWd} / \mathrm{L}$ & $* \mathrm{H} /[-\mathrm{ATR}-\mathrm{low}]$ & MAX(ATR) \\
\hline a. [mغ̀tf] & & $* !$ & \\
\hline b. [métf] & $* !$ & & \\
\hline c. [métf] & & & * \\
\hline
\end{tabular}

Having different constraint rankings in the native phonology and the loanword phonology can be achieved using indexed constraints (Itô \& Mester 1995, 1999, Pater 2007, Jurgec, to appear) or cophonologies (Inkelas et al. 1997, Anttila 2002). The argument in this paper is consistent with either approach.

\section{Conclusions}

We have shown that the interaction of tone and ATR in Slovenian supplies evidence for a constraint that directly relates tone and vowel quality, ${ }^{*} \mathrm{H} /[-\mathrm{ATR}-\mathrm{low}]$. Most previously reported cases of vowel quality-tone interactions were problematic due to the fact that the interactions could be interpreted by the mediation of some other feature/prosodic 
constituent between vowel quality and tone. Since Slovenian does not distinguish quantity or phonation type on vowels, and the pattern holds regardless of neighboring consonants or syllable structure, it constitutes a particularly clear case of tone-vowel interactions.

In the native phonology, $* \mathrm{H} /[-\mathrm{ATR}-\mathrm{low}]$ causes mid lax vowels to surface with a Low tone. In the loanword phonology, where High tones are required, the same constraint causes mid vowels to surface tense. This heterogeneity of process and homogeneity of target (a "conspiracy" in terms of Kisseberth 1970) is a hallmark of markedness constraints.

The proposed constraint, *H/[-ATR - low $]$, directly relates a supra-segmental feature and a sub-segmental feature, contrary to de Lacy's (2007:299) proposal to disallow such constraints. The data at hand, however, makes such a constraint necessary for a complete account of the data.

\section{References}

Abramson, Arthur S. (1962). The vowels and tones of standard Thai: Acoustical measurements and experiments. International Journal of American Linguistics 28. III.

Alderete, John (2001). Dominance effects as trans-derivational anti-faithfulness. Phonology 18. 201-253.

Anttila, Arto (2002). Morphologically conditioned phonological alternations. Natural Language and Linguistic Theory 20. 1-42.

Archangeli, Diana \& Douglas Pulleyblank (1994). Grounded Phonology. Cambridge, MA: MIT Press.

Assmann, Peter F. \& Terrance M. Nearey (2007). Relationship between fundamental and formant frequencies in voice preference. Journal of the Acoustical Society of America 122. EL35-EL43. 
Cahill, Michael (2001). The unusual tone system of Awad Bing. Paper presented at the 75th Annual Meeting of the Linguistic Society of America (Washington, January 4-7, 2001).

Cohn, C. Abigail (1993). Voicing and vowel height in Madurese. In Jerold A. Edmondson \& Kenneth J. Gregerson (eds.) Tonality in Austronesian Languages, Honolulu, HI: University of Hawaii Press. 107-122.

Connel, Bruce (2002). Tone languages and the universality of intrinsic F0: evidence from Africa. Journal of Phonetics 30. 101-129.

de Lacy, Paul (2002). The interaction of tone and stress in Optimality Theory. Phonology 19. $1-32$.

de Lacy, Paul (2007). The interaction of tone, sonority, and prosodic structure. In Paul de Lacy (ed.) The Cambridge Handbook of Phonology, Cambridge: Cambridge University Press. 281-307.

Dimmendaal, Gerrit J. (1983). The Turkana Language. Dordrecht: Foris.

Dimmendaal, Gerrit J. \& Anneke Breedveld (1986). Tonal influence on vocalic quality. In Koen Borgens, Harry van der Hulst \& Mous Maarten (eds.) The Phonological Representation of Suprasegmentals, Dordrecht: Foris. 1-34.

Edmondson, Jerold A. \& Kenneth J. Gregerson (1993). Western Cham as a register language. In Jerold A. Edmondson \& Kenneth J. Gregerson (eds.) Tonality in Austronesian Languages, Honolulu, HI: University of Hawaii Press. 61-74.

Fant, Gunnar (1970). Acoustic Theory of Speech Production. Paris: Mouton de Gruyter. 
Gregerson, Kenneth J. (1976). Tongue-root and register in Mon-Khmer. In Phillip N. Jenner, Laurence C. Thompson \& Stanley Starosta (eds.) Austroasiatic Studies, Honolulu, HI: Unoversity of Hawaii Press, vol. 1. 323-369.

Hermans, Ben \& Marc van Oostendorp (2007). Can low tone trigger velarization? Paper presented at the Workshop on segments and tone, Maatrens Instituut (Amsterdam, June $7-8,2007)$.

Herrity, Peter (2000). Slovene: A Comprehensive Grammar. London, New York: Routledge.

Hombert, Jean-Marie (1977). Development of tones from vowel height. Journal of Phonetics 5. 9-16.

Hombert, Jean-Marie (1978). Consonant types, vowel quality and tone. In Victoria A. Fromkin (ed.) Tone: A Linguistic Survey, New York: Academic Press. 77-112.

Hombert, Jean-Marie, John J. Ohala \& William G. Ewan (1979). Phonetic explanations for the development of tones. Language 55. 37-58.

Hyman, Larry \& Russell G. Schuh (1974). Universals of tone rules: evidence from West Africa. Linguistic Inquiry 5. 81-115.

Inkelas, Sharon, Orhan C. Orgun \& Cheryl Zoll (1997). The implications of lexical exceptions for the nature of grammar. In Iggy Roca (ed.) Derivations and constraints in phonology, Oxford: Clarendon Press. 393-418.

Itô, Junko \& Armin Mester (1995). Japanese phonology. In John A. Goldsmith (ed.) The Handbook of Phonological Theory, Cambridge, MA and Oxford: Blackwell. 817-838.

Itô, Junko \& Armin Mester (1999). The phonological lexicon. In Natsuko Tsujimura (ed.) The Handbook of Japanese Linguistics, Oxford: Blackwell. 62-100. 
Jiang-King, Ping (1999). Tone-Vowel Interaction in Optimality Theory. München: Lincom Europa.

Jurgec, Peter (2005). Formant frequencies of Standard Slovenian vowels. Govor 22. 127144.

Jurgec, Peter (2006). Formant frequencies of vowels in tonal and non-tonal Standard Slovenian. Slavistična revija 54. 467-478.

Jurgec, Peter (2007a). Acoustic analysis of lexical tones in contemporary standard Slovenian. In Proceedings of the 16th International Congress of Phonetic Sciences, Saarbrücken: Universität des Saarlandes, vol. 2. 1089-1092.

Jurgec, Peter (2007b). Novejše besedje s stališča fonologije: primer slovenščine [Neologisms in Phonology: The Case of Slovenian]. Ph.D. dissertation, University of Ljubljana.

Jurgec, Peter (to appear). Disjunctive lexical stratification. Linguistic Inquiry .

Kingston, John (2007). Segmental influences on F0: Controlled or automatic. In Carlos Gussenhoven \& Thomas Riad (eds.) Tones and Tunes, Berlin: Mouton de Gruyter, vol. 2. $171-210$.

Kisseberth, Charles (1970). On the functional unity of phonological rules. Linguistic Inquiry 1. 291-306.

Kurisu, Kazutaka (2001). The Phonology of Morpheme Realization. Ph.D. dissertation, University of California, Santa Cruz, Santa Cruz. Available on Rutgers Optimality Archive, ROA 410, http://roa.rutgers.edu.

Lenček, Rado L. (1981). The structure and history of the Slovene language. Columbus, OH: Slavica Publishers. 
Matisoff, James A. (1973). The grammar of Lahu. Berkeley, CA: University of California Press.

Morén, Bruce \& Elizabeth Zsiga (2006). The lexical and post-lexical phonology of Thai tones. Natural Language and Linguistic Theory 24. 113-178.

Mutaka, Ngessimo M. (1994). The Lexical Tonology of Kinande. München, Newcastle: Lincom Europa.

Nitta, Tetsuo (2001). The accent system in the Kanazawa dialect: The relationship between pitch and sound segments. In Shigeki Kaji (ed.) Proceedings of the Symposium CrossLinguistic Studies of Tonal Phenomena: Tonogenesis, Japanese Accentology, and Other Topics, Tokyo: Tokyo University of Foreign Studies. 153-185.

Odden, David (2001). Comments on "the accent system in the Kanazawa dialect: The relationship between pitch and sound segments". In Shigeki Kaji (ed.) Proceedings of the Symposium Cross-Linguistic Studies of Tonal Phenomena: Tonogenesis, Japanese Accentology, and Other Topics, Tokyo University of Foreign Studies. 187-193.

Odden, David (2007). Features impinging on tone. Paper presented at the Workshop on segments and tone, Maatrens Instituut (Amsterdam, June 7-8, 2007).

Ohala, John J. (1973). The physiology of tone. In Larry Hyman (ed.) Consonant types and tone, Los Angeles: University of Southern California. 3-14.

Ohala, John J. (1978). Production of tone. In Victoria A. Fromkin (ed.) Tone: A Linguistic Survey, New York: Academic Press. 5-39.

Ohala, John J. \& Brian W. Eukel (1987). Explaining the intrinsic pitch of vowels. In Robert Channon \& Linda Shockey (eds.) In honor of Ilse Lehiste, Dordrecht: Foris. 207-215. 
Pape, Daniel \& Christine Mooshammer (2006). Is intrinsic pitch language-dependent? Evidence from a cross-linguistic vowel pitch perception experiment. In Proceedings of the ISCA International Workshop on Multilinguistic MULTILING, Stellenbosch.

Pater, Joe (2007). The locus of exceptionality: Morpheme-specific phonology as constraint indexation. In Leah Bateman, Michael O’Keefe, Ehren Reilly \& Adam Werle (eds.) University of Massachusetts Occasional Papers in Linguistics 32: Papers in Optimality Theory III, Amherst: GLSA, University of Massachusetts. 259-296. Available on Rutgers Optimality Archive, ROA 866, http://roa.rutgers.edu.

Petek, Bojan, Rastislav Šuštaršič \& Smiljana Komar (1996). An acoustic analysis of contemporary vowels of the standard Slovenian language. In Proceedings ICSLP 96: Fourth International Conference on Spoken Language Processing, October 3-6, 1996, Philadelphia, PA, USA, Newark, DE. 133-136. Available online at http://www.asel.udel.edu/icslp/cdrom/vol1/820/a820.pdf.

Prince, Alan \& Paul Smolensky (1993/2004). Optimality Theory: Constraint Interaction in Generative Grammar. Piscateway, NJ: Blackwell. Available on Rutgers Optimality Archive, ROA 537, http://roa.rutgers.edu.

Schuh, Russell G. (1971). Ngizim phonology. Ms., University of California Los Angeles.

Spears, Richard A. (1968). Tonal dissimilation in Maninka. Journal of African Languages 7. $88-100$.

Srebot Rejec, Tatjana (1988). Word Accent and Vowel Duration in Standard Slovene: An Acoustic and Linguistic Investigation. No. 226 in Slavistische Beiträge, München: Otto Sagner.

Svantesson, Jan-Olof (1988). U. Linguistics of the Tibeto-Burman Area 11. 64-133. 
Svantesson, Jan-Olof (1991). Hu - a language with unorthodox tonogenesis. In Jeremy Davidson (ed.) Austroasiatic Languages - Essays in honour of H. L. Shorto, London: SOAS. 67-79.

Svantesson, Jan-Olof (2001). Tonogenesis in Southeast Asia - Mon-Khmer and beyond. In Shigeki Kaji (ed.) Proceedings of the Symposium Cross-Linguistic Studies of Tonal Phenomena: Tonogenesis, Japanese Accentology, and Other Topics, Tokyo: Tokyo University of Foreign Studies. 45-58.

Tang, Katrina (2008). The Phonology and Phonetics of Consonant-Tone Interaction. Ph.D. dissertation, University of California, Los Angeles. Available on Rutgers Optimality Archive, ROA 974, http://roa.rutgers.edu.

Toporišič, Jože (1968). Liki slovenskih tonemov. Slavistična revija 16. 315-393.

Toporišič, Jože (2000). Slovenska slovnica. Maribor: Obzorja.

Trigo, Loren (1991). On pharynx-larynx interactions. Phonology 8. 113-136.

Šuštaršič, Rastislav, Smiljana Komar \& Bojan Petek (1995). Slovene. Journal of the International Phonetic Association 25. 86-90.

Šuštaršič, Rastislav, Smiljana Komar \& Bojan Petek (1999). Slovene. In Handbook of the International Phonetic Association, Cambridge: Cambridge University Press. 135-139.

Whalen, D. H. \& Andrea G. Levitt (1995). The universality of intrinsic $F_{0}$ of vowels. Journal of Phonetics 23. 349-366.

Wolf, Matthew (2007). For an autosegmental theory of mutation. In Leah Bateman, Michael O'Keefe, Ehren Reilly \& Adam Werle (eds.) University of Massachusetts Occasional Papers in Linguistics 32: Papers in Optimality Theory III, Amherst: GLSA, 
University of Massachusetts. 315-404. Available on Rutgers Optimality Archive, ROA 754, http://roa.rutgers.edu.

Yue Hashimoto, Oi-kan (1972). Studies in Yue dialects, 1. Phonology of Cantonese. Cambridge: Cambridge University Press.

Zee, Eric (1980). Tone and vowel quality. Journal of Phonetics 6. 247-258. 